\title{
STUDIES ON MARINE FLAGELLATES
}

\section{MORPHOLOGY AND MICROANATOMY OF A NEW SPECIES OF CHRYSOCHROMULINA}

\author{
By MARY PARKe
}

The Plymouth Laboratory

\author{
Irene Manton and B. Clarke \\ Botany Department, Leeds University
}

(With total of 37 Figures in text and on Plates I-X)

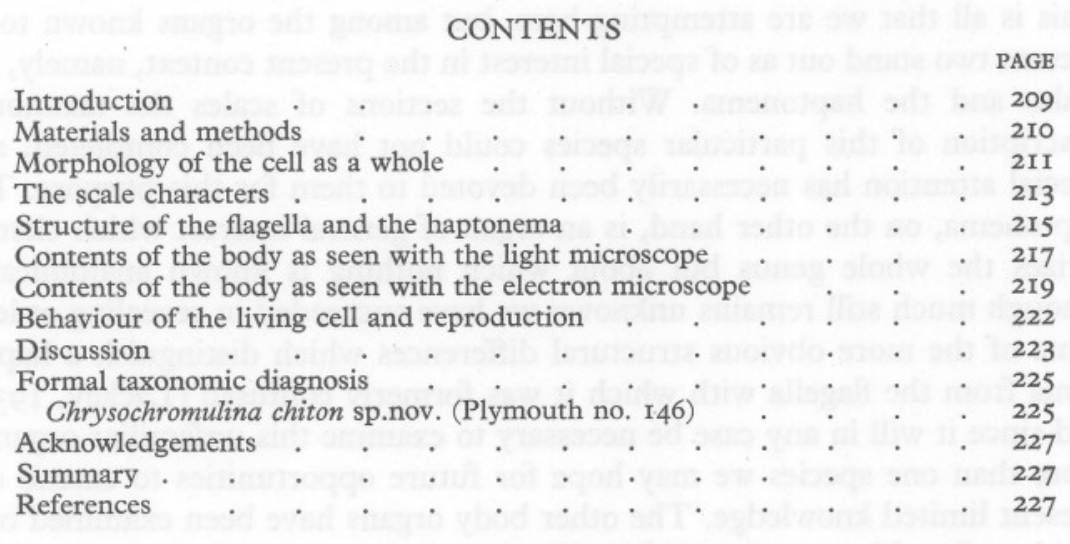

\section{INTRODUCTION}

In our previous descriptions of new species of flagellates provisionally referred to the genus Chrysochromulina (Parke, Manton \& Clarke, 1955, 1956) the electron microscope has been used to amplify knowledge of the external morphology but not of the internal structure. This limitation was known to be temporary, but considerable effort has had to be expended on perfecting methods of handling these very delicate organisms before it could be overcome. That to some extent this has now been achieved is due to two independent circumstances, on the one hand a fairly large and relatively resistant organism with some specially favourable features about its external appendages, and on the other hand the opportunity of examining good sections with a more powerful microscope than that normally available to us in Leeds.

The optical requirements for the electron microscopy of thin sections of biological material are far more stringent than for shadow-cast whole mounts 
and without the RCA microscope at the Rockefeller Institute, or some equivalent instrument, the sections reproduced here could not have been effectively studied. That this microscope was made available to one of us (I. M.) during a 2 weeks' visit to New York at Christmas 1956 is a matter for very lively personal gratitude to Dr K. R. Porter and other members of the staff of the Cytology Section who were at hand at a holiday period. As a result, although several other problems were studied during this visit, the work on the new flagellate advanced sufficiently far to reach a state suitable for publication with only 4 days' further work on a high-resolution microscope in England (the Siemens microscope at the Aeon Laboratories at Egham, Surrey).

It should perhaps be explained, however, that in a study of this kind, even without the present limitation of access to suitable microscopes, completeness in the description of fine structure is rarely a practicable objective at the first attempt. With every new type of cell it is a sufficient undertaking to identify the various organs present and determine their salient structural features. This is all that we are attempting here, but among the organs known to be present two stand out as of special interest in the present context, namely, the scales and the haptonema. Without the sections of scales the taxonomic description of this particular species could not have been completed, and special attention has necessarily been devoted to them for this purpose. The haptonema, on the other hand, is an organ of general interest which characterizes the whole genus but about which nothing is known anatomically. Though much still remains unknown we have succeeded in revealing at least some of the more obvious structural differences which distinguish a haptonema from the flagella with which it was formerly confused (Lackey, 1939), and since it will in any case be necessary to examine this unfamiliar organ in more than one species we may hope for future opportunities to extend our present limited knowledge. The other body organs have been examined only incidentally. Most, and probably all, of those detected with the light microscope have been found with the electron microscope and a few others have been added. But in all, our study of structure has been limited to the necessary minimum required for identification of the organ, since space as well as time would have precluded more detailed analysis.

\section{MATERIALS AND METHODS}

The material came from three separate isolates originally numbered 146,149 and 150 in the Plymouth collection. All three have been used for external morphology, but only culture I 46 was embedded. As on previous occasions each culture was unialgal though not bacteria-free.

The methods used for visual microscopy and for external morphology with the electron microscope have been exactly as in our previous papers. They are described in Parke et al. (1955), and therefore the only new details to mention 
are those concerned with the production of thin sections for the electron microscope.

Before embedding it is necessary to concentrate the cells by IO-I $5 \mathrm{~min}$ centrifugation at a speed which has to be determined by experiment. The test for successful centrifugation is that there should be sufficient cells in the concentrate and that these should still be swimming when examined under the light microscope; it is not necessary to remove all cells from the supernatant. The fixative ( $\mathrm{I} \%$ osmium tetroxide buffered to $\mathrm{pH} 7$ with acetate veronal in distilled water) is then poured on after removal of the supernatant and the tube is left undisturbed in a domestic refrigerator for I h. Alternatively, the concentrated cells may be sucked up with a pipette and squirted into the fixative before being again spun down for ease of handling.

The procedure for washing, dehydration and embedding in $n$-butyl methacrylate is standard. It is probably enough to say that the fixative is washed out by two rapid changes of buffer and the dehydration is by means of graded alcohols-30, 50, 70, 90\% (two changes), absolute (two changes)-each applied for a quarter of an hour. After this the material is transferred by stages to the destabilized monomer which is polymerized by the aid of the commercial catalyst Luperco in an oven at $48^{\circ} \mathrm{C}$.

The sections were cut on a Porter-Blum Serval microtome in the Leeds Botany Department using a glass knife.

\section{MORPHOLOGY OF THE CELL AS A WHOLE}

The essential characteristics of the genus Chrysochromulina as at present construed have been discussed in previous papers (Parke et al., 1955, 1956), and therefore we propose to give close attention in this section only to those details by which our new species is distinguishable from others.

The general shape of the cell is best illustrated in Figs. I-7, since the photographs assembled in P1. I are necessarily based on dried material. In an actively growing culture $75 \%$ of the cells are from 5 to $8 \mu$ diameter, while $8 \%$ are between 4 and $5 \mu$; the remaining $17 \%$ are incipient fission stages from 8 to го $\mu$. These dimensions are thus somewhat larger than those of C. kappa, C. minor and C. brevifilum, though slightly smaller than those of C. ericina, C. ephippium and $C$. alifera. The two flagella are equal in length in only about $25 \%$ of the cells, the remainder having them subequal; $50 \%$ of these show a difference of $\mathrm{I}-2 \mu, 45 \%$ show a difference of $2-4 \mu$ and $5 \%$ a difference of $5-6 \mu$ between the two flagella of an individual. This degree of asymmetry is slightly greater than that described for $C$. alifera though the flagellar movement appears to be homodynamic. The haptonema is relatively short, being only a little longer than the flagella (cf. P1. I). This detail recalls C. ericina and, as in that species, the attachment of the three appendages to the body is slightly 'off centre' in a depression at the pole which commonly faces 


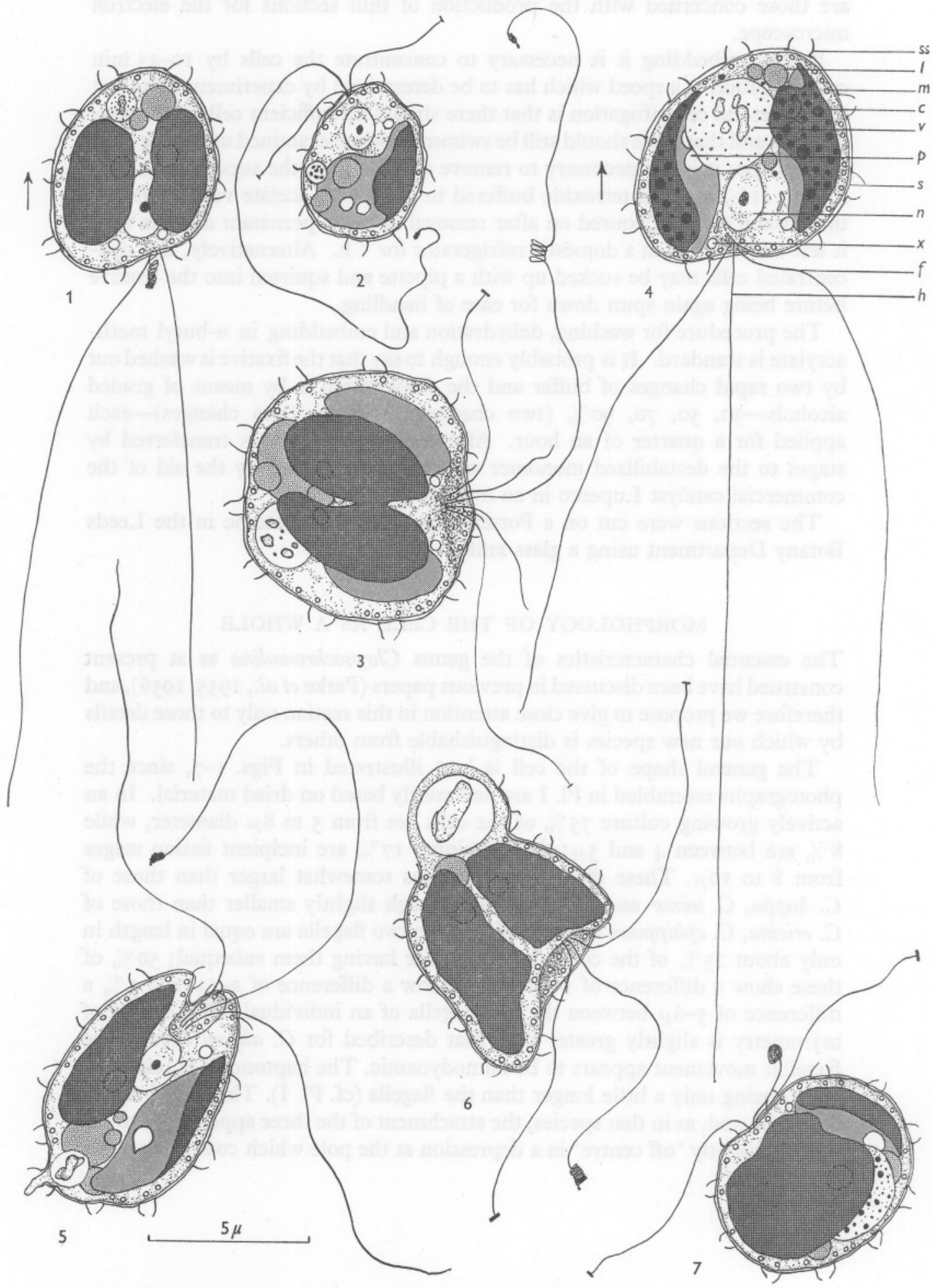

Figs. I-7. Chrysochromulina chiton sp.nov. $(\times 5000)$ 
backwards during swimming. Further details regarding the behaviour of the cell in life will be found on p. 222.

In spite of a superficial resemblance to some of our other species in various details of relative dimensions our new species is sharply distinguished from everything that we have previously described by its very remarkable and large scales. These are so big (up to nearly $3 \mu$ in diameter) that they can be seen individually with the light microscope on a dried preparation (cf. Fig. Io, P1. I), but even without drying they are liable to become detached from the surface of the body in sheets which stain readily with cresyl blue and are then clearly visible. In section they are equally distinctive in ways which will be described below. For these reasons we propose to name our new species $C$. chiton to draw attention to the remarkable scale characters.

\section{THE SCALE CHARACTERS}

The large size and spectacular appearance of the scales can be seen in Fig. II, Pl. I, and in Pls. II and III. They are manifestly of two kinds, each with characteristic differences in the appearance of the two faces. There are smaller, roundish or oval scales, each with a rim and a radiating pattern of ridges on one face which is absent from the other (see specially Figs. I6 and 17). These represent a general type of scale which we have encountered not uncommonly (1955, 1956), often in association with others of markedly different appearance. The second type of scale and the one characteristic of our new species has not previously been encountered. These scales are much larger and manifestly bipartite, having a wide rim delimited from an oval centre by a ridge which suggests that these two parts cannot have been in the same plane in life, although in the flattened condition produced by drying it is not possible to deduce what their mutual relations may have been. Unconsciously one is influenced by their astonishing resemblance to straw hats. The pattern of

\section{Legends to Text-figs. $1-7$ \\ Chrysochromulina chiton sp.nov. $(\times 5000)$}

Fig. I. Individual swimming with flagella and haptonema behind body in position characteristic for the species during rapid swimming.

Fig. 2. Anchored individual with one chromatophore; haptonema nearly fully extended but bent.

Fig. 3. Early fission stage: four flagella, one haptonema, chromatophores dividing.

Fig. 4. Individual gliding without rotating, with flagella and haptonema behind body in position characteristic for the species during gliding movement. $c$, chromatophore containing saturated lipoid globules stained by Sudan Black; $f$, flagellum; $h$, haptonema; $l$, leucosin vesicle; $m$, muciferous body; $n$, nucleus; $p$, pyrenoid; $s$, smaller plate-shaped scale; ss, larger saucer-shaped scale; $v$, vacuole containing ingested bacteria; $x$, mitochondrion?

Fig. 5. Individual swinging round on partly extended, bent, anchored haptonema; recently ingested bacteria in vacuole at non-flagellar pole.

Fig. 6. Anchored individual with haptonema coiled at distal end; recently ingested Monas cell in vacuole at non-flagellar pole.

Fig. 7. Anchored individual with haptonema coiled; large vacuole containing granules showing Brownian movement near non-flagellar pole. 
sculpturing which is partly responsible for this illusion is present on one face only, the other face being smooth (compare $\mathrm{S}_{1}$ with $\mathrm{S}_{2}$ in Fig. I5, P1. II).

The true shape of both types of scale is at once made clear from a section, e.g. Fig. 30, Pl. IX. The large scales are not hat-shaped but saucer-shaped, and the small scales are plate-like with a rim sharply flexed towards the upper surface. Both kinds of scale become detached from the cells so easily that these are commonly naked when sectioned though scales may litter the field cut at all angles and without orientation to a surface (Pl. IV, etc.). The two characteristic types of profile are easily picked out. Occasionally, however, a favourable cell may retain its scales in position and two are illustrated here (P1. VIII and Fig. 29, Pl. IX) from each of which the arrangement of the scales on the cell surface is obvious. They form a single layer with the two scale types so arranged that the small scales alternate with the large ones, occupying the interstices between them. In surface view this must mean that each large scale is surrounded by a ring of 5-6 small scales in a manner which is partly retained in the detached mat illustrated in Pl. III.

Apart from the evidence on scale arrangement, the cells of Figs. 28 and 29, Pls. VIII and IX, are important for providing information regarding the relative positions of the patterned versus patternless scale faces with respect to the cell surface. In both cases the scale shape in section combined with the information from shadowcast material makes it clear that the patterned surface lies against the cell body and the relatively patternless surface outwards. This is in exact agreement with the position deduced from the evidence of the spined scales in C. ephippium (1956, p. 402).

A fuller interpretation of the nature of the patterning on the scale faces cannot be arrived at without knowledge of their mode of growth. There is, however, no doubt that, at least for the larger scales, there are two quite distinct layers of material present which in section can be seen separately in the angle where the rim joins the central plate (Pl. VIII). Though the

\section{Explanation of Plates I-II \\ Chrysochromulina chiton sp.nov.}

I

Figs. 8-Io. Three dried cells photographed with the light microscope to show the flagella and haptonemata extended; detached scales visible near arrows in Fig. 10. $\times$ I000.

Fig. II. Low-power electron micrograph (M489.I0) of a cell with a coiled haptonema; the body scales very conspicuous. $\times 3000$

Fig. 12. Similar but with haptonema extended and scales not conspicuous. M380.24, $\times 3000$.

Fig. 13. Tip of the haptonema and one flagellum of Fig. 12 more highly magnified. M 380.15 , $\times$ 10,000.

II

Fig. I4. Tip of a haptonema to show apical swelling and sheath. M 480.6, $\times$ r8,000.

Fig. I5. A cell with scales, SI showing smooth outer face, $S_{2}$ showing patterned lower face. M $301.6, \times 15,000$.

Fig. 16. A field of detached scales more highly resolved. Mid 502.5, $\times 30,000$. 
8


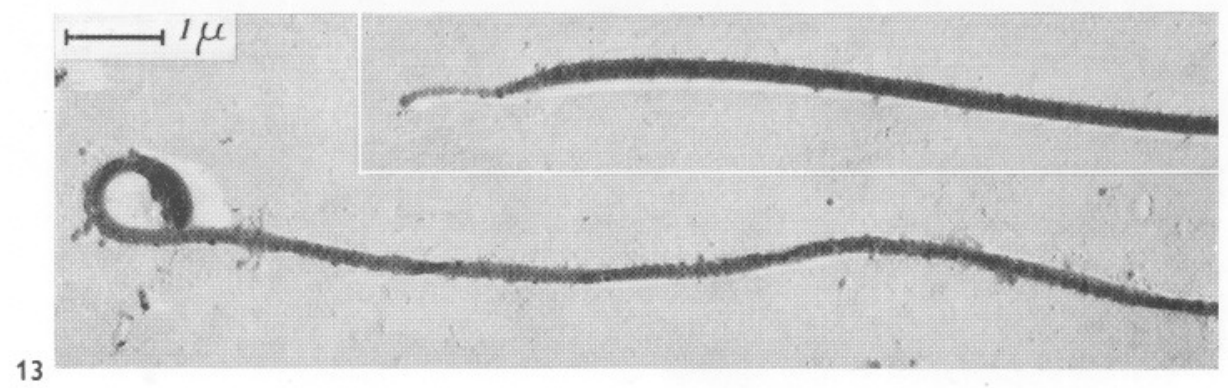

(Facing p. 214) 

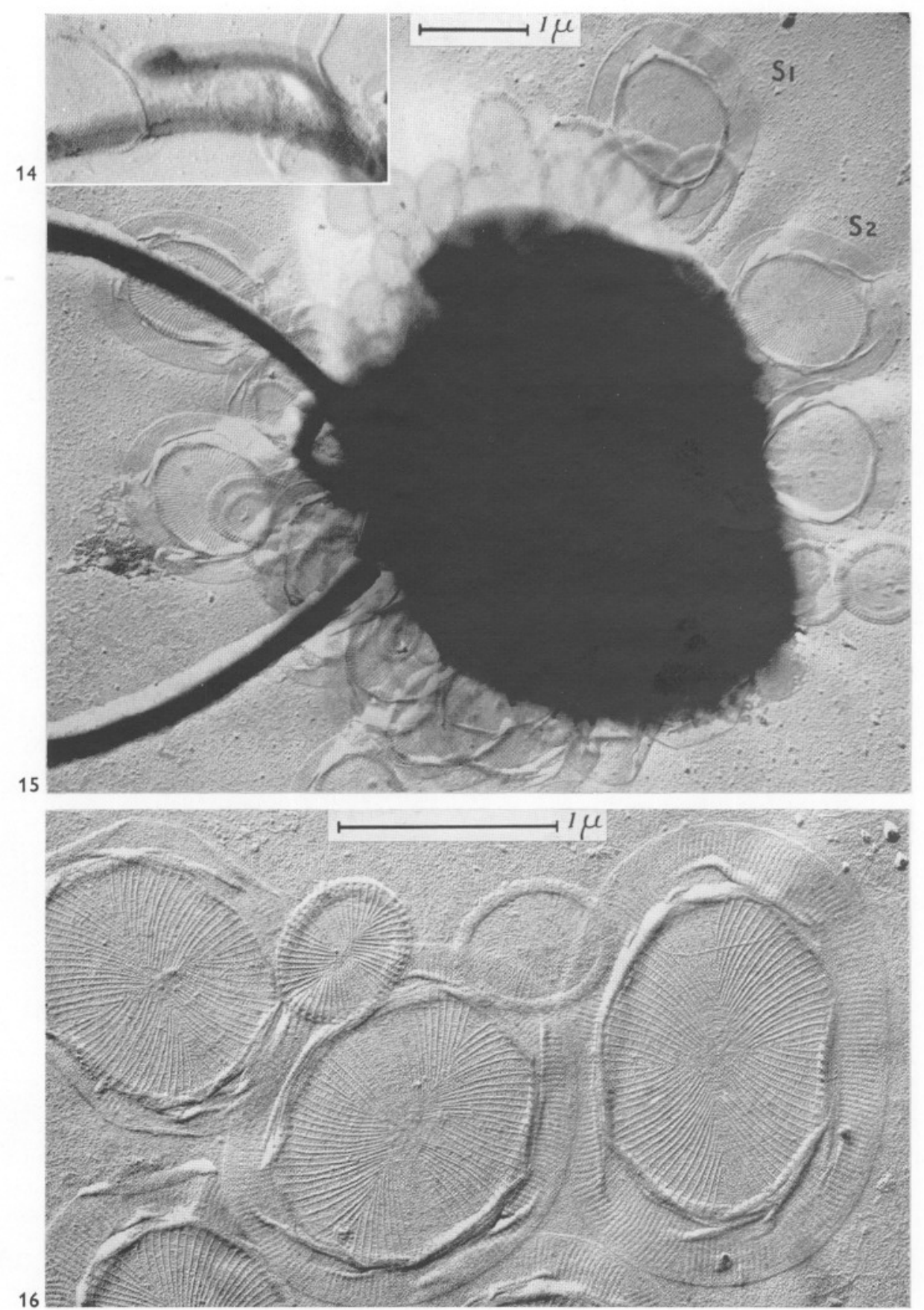
sculpturing is confined to the lower layer, it is probable that this layer is actually compound since our best resolved pictures of the patterned surface, Fig. 16, Pl. II, give a strong suggestion of interwoven fibres rather than sculpturing in the strict sense.

\section{STRUCTURE OF THE FLAGELLA AND THE HAPTONEMA}

The two types of filiform appendages are visible in Pl. I and part of Pl. II. The club-shaped tip of the haptonema contrasting with the attenuated knobbed apices of the flagella (Fig. I3) is a familiar feature from other species. That the axis of the haptonema is narrower than that of a flagellum is also familiar, as is the occasional appearance as of a loose sheath covering the haptonema in favourable preparations (Fig. I4).

The internal structure of flagella is now so well known that they can be recognized at sight in almost any type of section. In Fig. 30, Pl. IX, for example, there is a good transverse section showing the outer membrane, the ring of nine strands and the central pair, though the latter are not separately resolved. Other views will be found in several of the micrographs, but special attention can usefully be given to the one on the right of Fig. 2I, Pl. V, since this, though somewhat flattened, shows the two central strands clearly and also traces of the split in some of the peripheral strands.

The other objects contained in the various micrographs on $\mathrm{Pl}$. V are almost all parts of coiled haptonemata cut in various directions. In studying the internal structure of the haptonema the first and major difficulty is identifying it in section, since its attachment to the body cannot usually be traced. The coiled nature of the haptonema, however, in this species made identification possible, since in section the haptonema gave clusters of small profiles with an opaque micro-structure which could be distinguished from other small circular profiles (flagella, bacteria, and the debris from broken cells) which crowd the field. The clusters of small profiles are a sure indication of the presence of a haptonema once the general characteristics of flagella and bacteria, both of which are larger than haptonemata in section, have been recognized. A characteristic field containing a haptonema is reproduced at a low magnification in $\mathrm{Pl}$. IV, and more highly magnified parts of four different specimens are included in Pl. V.

A very common fixation artifact which is unavoidably represented in parts of each of the four haptonemata reproduced in Pl. V is 'blistering'. This is almost certainly due to the presence of osmotically active materials beneath a relatively impermeable membrane, and the local distension of this membrane may cause not only a blister-like swelling of the surface but also distortion of the more resistant internal parts of the organ. In flagella, where this artifact is well known, the axis may become bent within the blister so that certain planes of section will suggest the presence of two or more axes within a 
common skin. Something similar is occurring in parts of all the haptonemata illustrated in P1. V and therefore not every profile can be interpreted as normal. Since, however, all sections in any one cluster belong to one and the same organ it is generally possible to distinguish undistorted sections as such when the plane of cutting is favourable.

The best transverse sections in Figs. I9-2I are indicated by arrows, and Figs. 2I $a$ and $b$ represent two successive sections reproduced side by side. Some other profiles in the various figures are oblique or longitudinal. Wherever the orientation is adequate, however, there is complete agreement in the numerical details displayed. In contrast to the flagella a haptonema possesses at least three concentric membranes surrounding a ring of seven strands, and the centre of the organ seems to be hollow. The sectional outline is probably circular except where flattening by pressure from the knife has occurred in cutting.

In many specimens, notably that of Fig. 20, the ring of seven strands (or tubes) is closely pressed to the inner side of the innermost membrane, but they are definitely not part of this membrane since they can become detached from it if blistering extends to the interior of the whole organ (Fig. 22). The outermost membrane in this specimen is greatly distended and within it the axis of the organ has been transversed three times. Two of these axial sections

\section{Explanation of Plates III-VI}

Chrysochromulina chiton sp.nov.

III

Fig. 17. A field of scales, reversed print. Mid $301.18, \times 20,000$.

\section{IV}

Fig. 18. Section of a field containing a haptonema (arrow) between cells and debris. $S_{37}$, $\times 12,500$.

\section{$\mathrm{V}$}

Fig. 19. Another section of the haptonema contained in Pl. IV at a different angle on the page; parts of eight profiles through the organ represented, the best transverse section indicated by the arrow. $S_{42}, \times 40,000$.

Fig. 20. Another haptonema showing parts of five sections through the axis, the best transverse section marked by an arrow. R86e, $\times 40,000$.

Fig. 2I. Transverse section of a flagellum (right) and parts of three sections of a haptonema (left), the best transverse section in the top left-hand corner $(b)$; another view of this from an adjacent section in $a . \mathrm{S}_{74}$ and $\mathrm{S} 83, \times 50,000$.

Fig. 22. Transverse section of another haptonema showing advanced 'blistering'; the flexed axis within the distended outer sheath has been traversed three times and in two of these the seven central strands have become detached from the innermost membrane, which is also greatly distended. $\mathrm{S}_{15}, \times 70,000$.

VI

Figs. 23-25. Three successive sections to show details of attachment of two pyrenoids to neighbouring chromatophores; a third pyrenoid, part of the nucleus near the surface, a mitochondrion and other inclusions also visible; for further details see PI. VII. Mid 502.11, S 97 and S 108, $\times$ 12,000. 


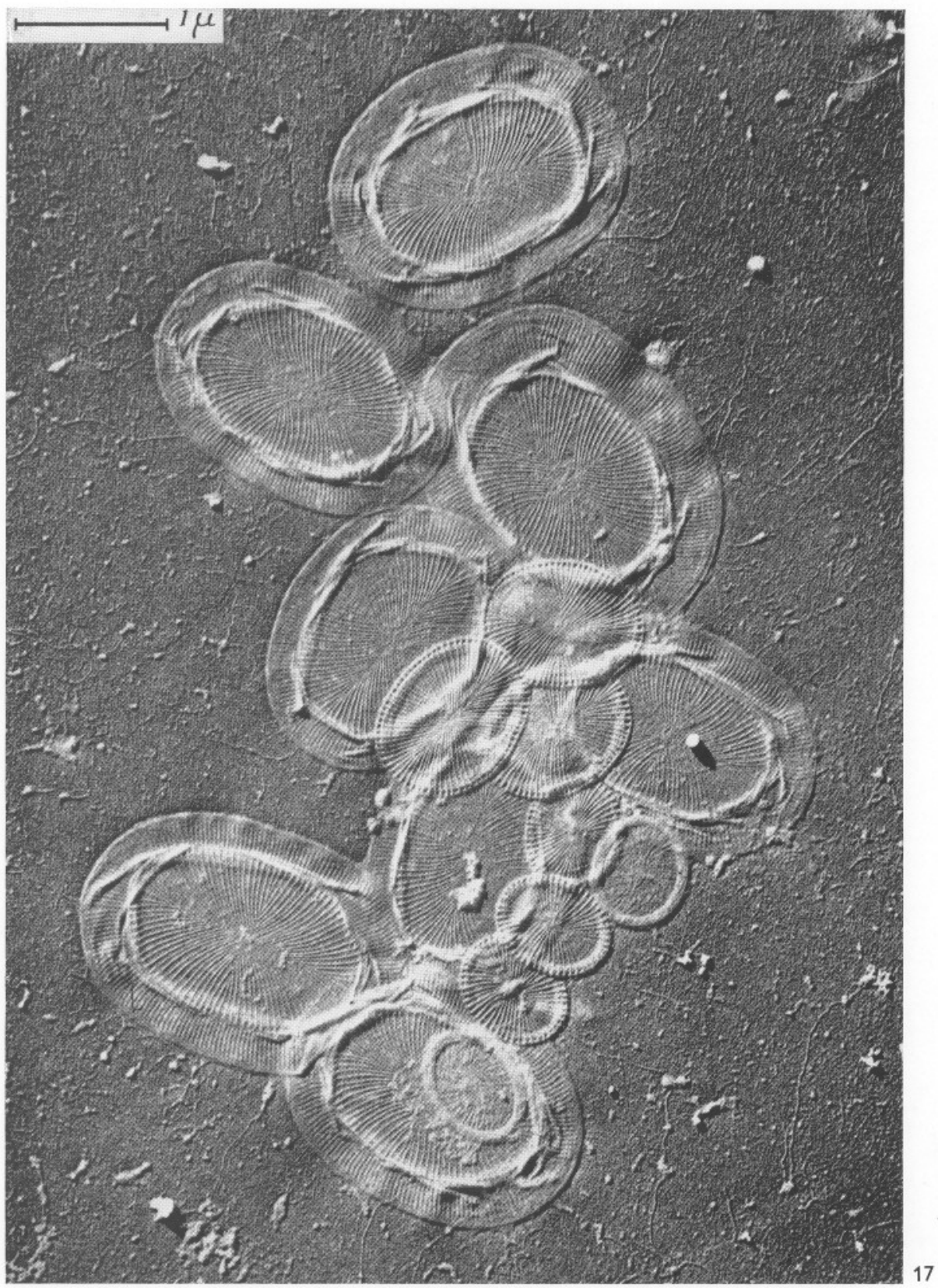

(Facing p. 216) 





Parke, Manton \& Clarke. Plate V
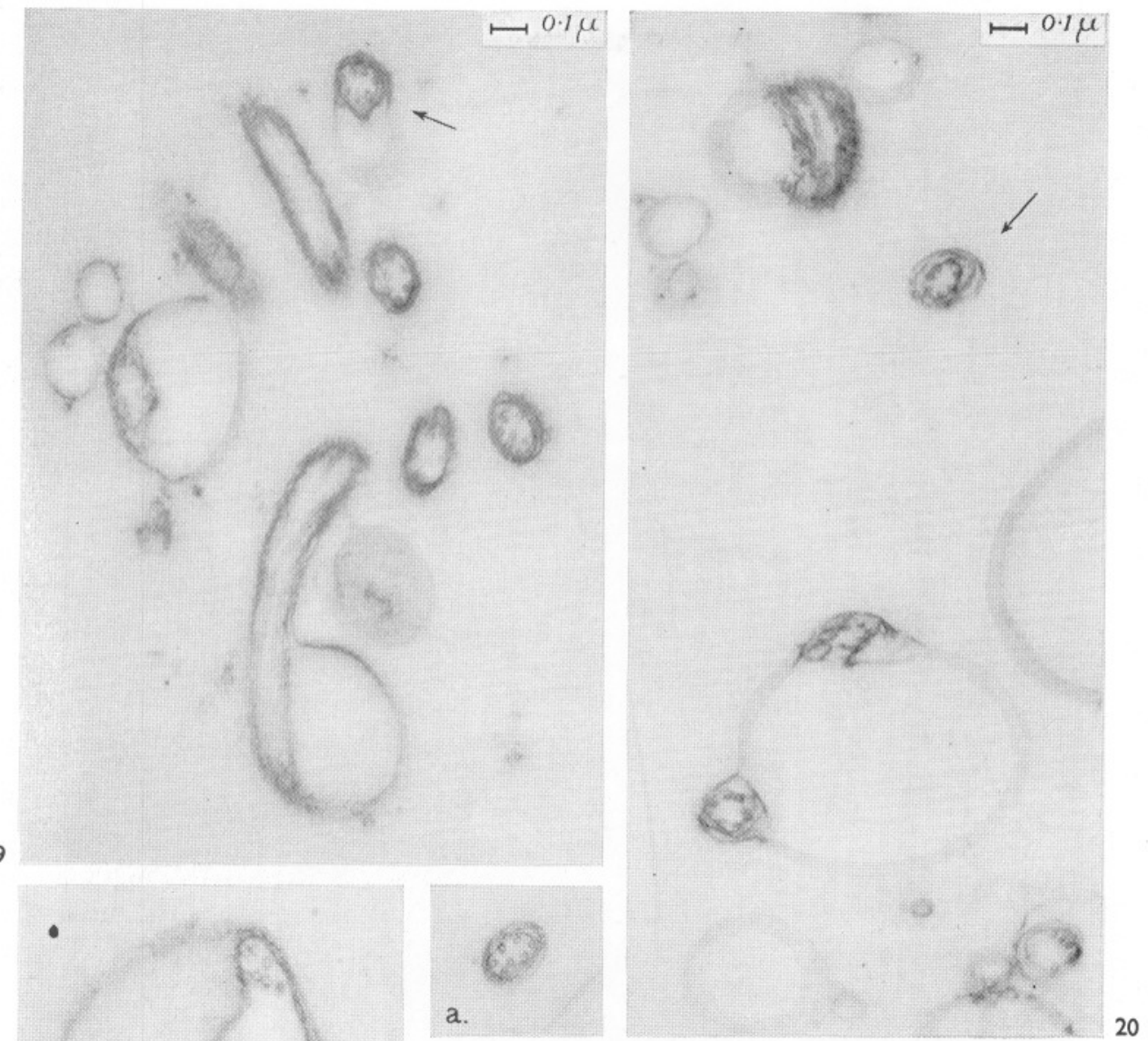

a.
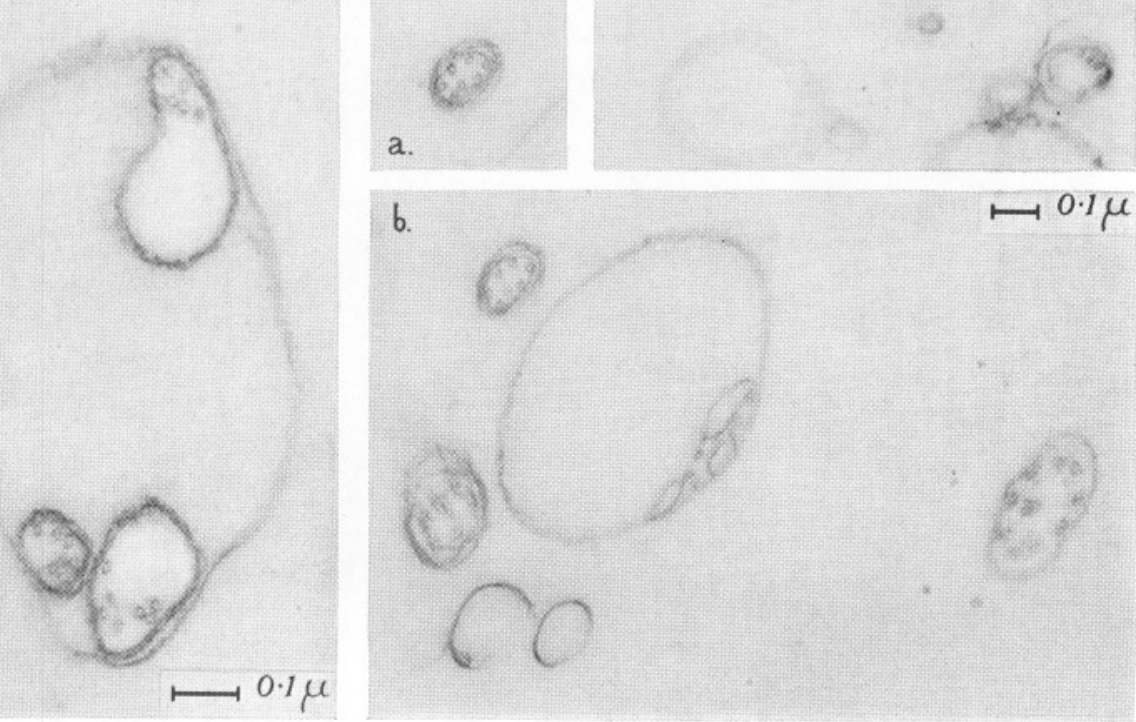

$21 a, b$ 
23
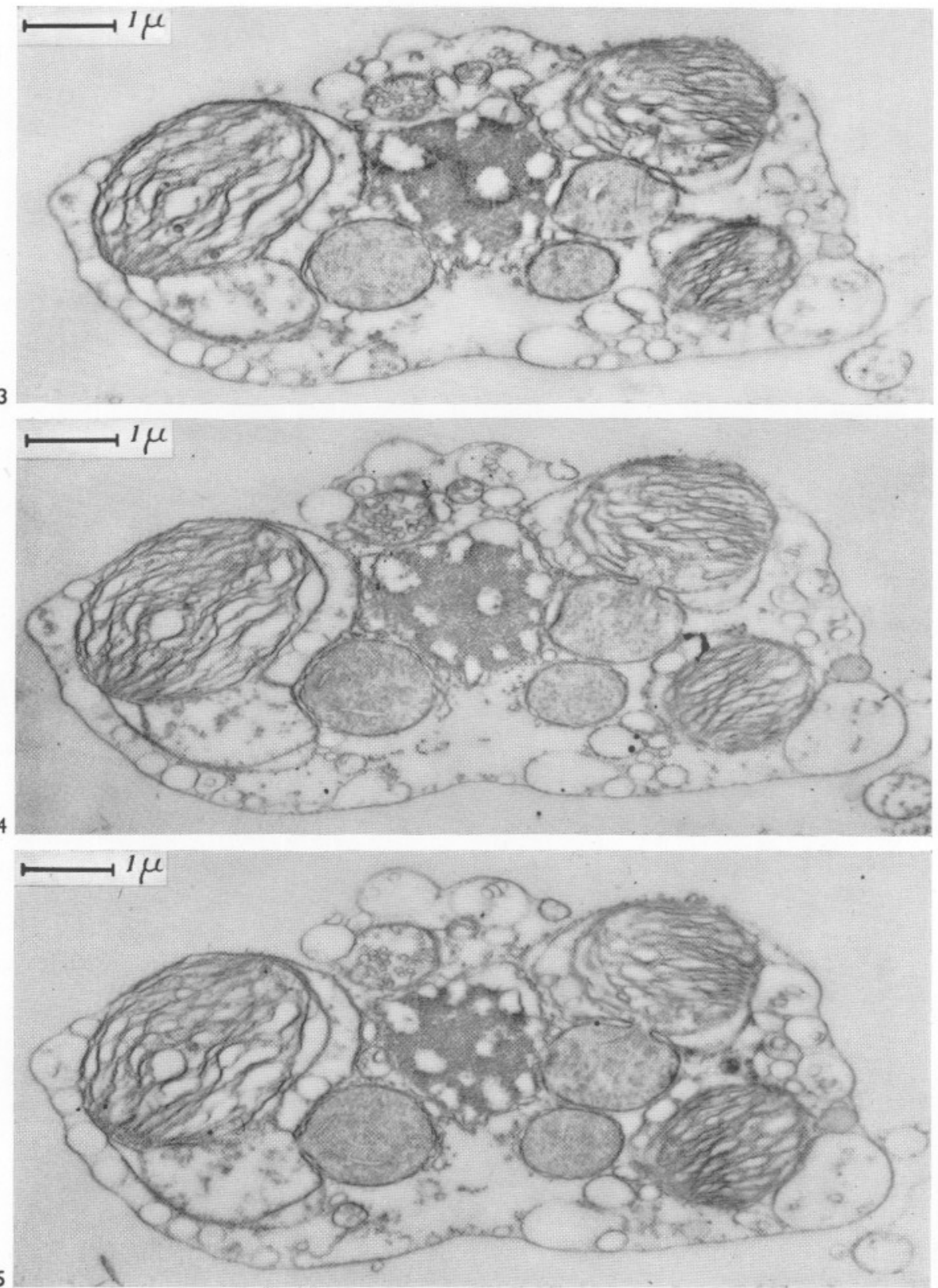
show distension of the remaining membranes also, and the fibres have become detached and are very clearly countable.

The longitudinal path of the internal haptonema fibres is visible in parts of Figs. I9 and 20. The strands run roughly parallel to each other, though Fig. I9 suggests a slightly spiral path. Minor undulations, never encountered in the peripheral fibres of flagella, are also detectable on individual fibres. There is therefore little doubt that the fibres themselves are different in character as well as in arrangement from those of the flagella.

Since not only the membranes but also the walls of the haptonema fibres are relatively thick, it is probable that both will reveal further microstructure when still higher resolution can be applied. This has not yet been seriously attempted. We likewise lack all anatomical information on the structure of the two extremities of the organ.

With regard to the details of attachment of the appendages to the cell we have some incidental observations for the flagella only. Two examples are illustrated in Figs. 33 and 34, P1. IX. Fig. 33 is important for demonstrating the spatial relation of the flagellar bases to a group of characteristic vesicles immediately below them which will be described below under golgi material. Fig. 34 is chosen as the best example so far obtained of the structural details of two bases, one in transverse section and the other in longitudinal section, both of which are probably flagella and not haptonemata. If this identification is correct the flagellum seen in longitudinal section seems to lack several of the normal structural details of a basal body, since there is no transverse partition at the level of the cell surface and the interior, which in other cases is hollow, seems occupied here by amorphous dark contents. The transverse section visible (see arrow) beside the posterior end of the longitudinal section shows a stellate outline corresponding to the nine peripheral strands and the centre is similarly filled with dark material. It therefore seems probable that some new features may be expected to exist in the basal parts of the flagella in this organism when they can be further studied.

\section{CONTENTS OF THE BODY AS SEEN WITH THE LIGHT MICROSCOPE}

With the light microscope an extremely thin pectic layer covering the body can be distinguished after staining with Ruthenian Red. The principal objects detectable inside the cell are as follows. (i) There are usually two or four golden brown chromatophores, each with internal striations clearly visible from the outer face and probably representing lamellae, and with a variable number (I to very numerous) of distinct vesicles (0.2-0.5 $\mu$ diameter) between the striations, which are soluble in alcohol and which stain intensely with Sudan black (Fig. 4) or Sudan IV especially when the latter is used as a vital stain, these reactions indicating saturated lipoid (cf. Doflein, I922, for 
Ochromonas). (ii) Against the inner face of each chromatophore, and probably attached to it, is a body of variable size $(0.5-1 \cdot 0 \mu)$, usually non-refractile and not staining with Sudan IV, which is probably a pyrenoid (cf. Schwarz, I932; Chadefaud \& Feldmann, 1949; Magne, 1952). A pink coloration of the surface with Sudan IV suggests the possible presence of a lipoid envelope covering this body. (iii) The cell nucleus commonly lies between the chromatophores but is liable to be displaced towards the cell surface from time to time. (iv) Two other bodies $(0 \cdot 5-\mathrm{I} \cdot 0 \mu)$, one spherical and one rod-shaped, can sometimes be seen close to the nucleus. (v) One or more food vacuoles are often present which move about the body from the non-flagellar pole towards the region of the pyrenoids before their contents are digested. (vi) Usually two or three leucosin vesicles of small size, but sometimes as large as $3 \mu$, are confined to the non-flagellar half of the cell and stain roseviolet with cresyl blue, a reagent which also picks out (pale blue) the very small muciferous bodies scattered over the cell surface but especially numerous near the flagellar pole, and some tiny bright blue granules perhaps associated with them. (vii) Osmium tetroxide stains one or two bodies of unsaturated fat

\section{Explanation of Plates VII-X}

\section{VII}

Fig. 26. A further section from the series in P1. VI, adjacent to Fig. 25. Mid 501.14, $\times$ I2,000.

Fig. 27. Enlarged detail from Fig. 26 to show the pyrenoid $(p y)$ and neighbouring structures more clearly, including part of nucleus $(N)$ and a mitochondrion $(m)$. Mid 50r.I5, $\times 20,000$.

\section{VIII}

Fig. 28. Section of a cell with an undisturbed covering of scales and also showing the nucleus $(N)$ and nucleolus; two obliquely cut flagella in the neighbourhood. S 7I, $\times 26,000$.

\section{IX}

Fig. 29. Section of a cell with an undisturbed covering of scales and also showing part of a leucosin cavity, muciferous bodies on the surface, two sections of flagella beneath the scales and therefore belonging to the cell, part of the nucleus, two fat bodies, mitochondria and other organelles also visible. S r $4, \times 16,000$.

Fig. 30. Section of two detached scales and a flagellum to show relative sizes and shapes. $\mathrm{S}_{2} \mathrm{I}, \times 30,000$.

Figs. 31,32 . Two adjacent sections through a group of muciferous bodies. S 88 and S78, magnification uncertain.

Fig. 33. Part of a section in the region of the flagellar bases. Si $97, \times 20,000$.

Fig. 34. Part of a section in the region of the flagellar bases, one in longitudinal section and the other in transverse section (arrow); adjacent organelles include leucosin cavity and muciferous bodies. S 202, $\times 28,000$.

\section{$\mathrm{X}$}

Fig. 35. A cell showing nucleus $(N)$, two chromatophores, a food vacuole, a fat body and golgi vesicles. $\mathrm{R} 88 \mathrm{c}, \times 10,000$.

Fig. 36. A cell showing nucleus, parts of leucosin cavities, mitochondria, three chromatophores and golgi area. S 9I, $\times$ ro,000.

Fig. 37. Details of the golgi area of Fig. 36 more highly magnified and placed at a different angle on the page; part of the nucleus $(N)$ and two chromatophores $(c)$ also present. S92, $\times 30,000$. 

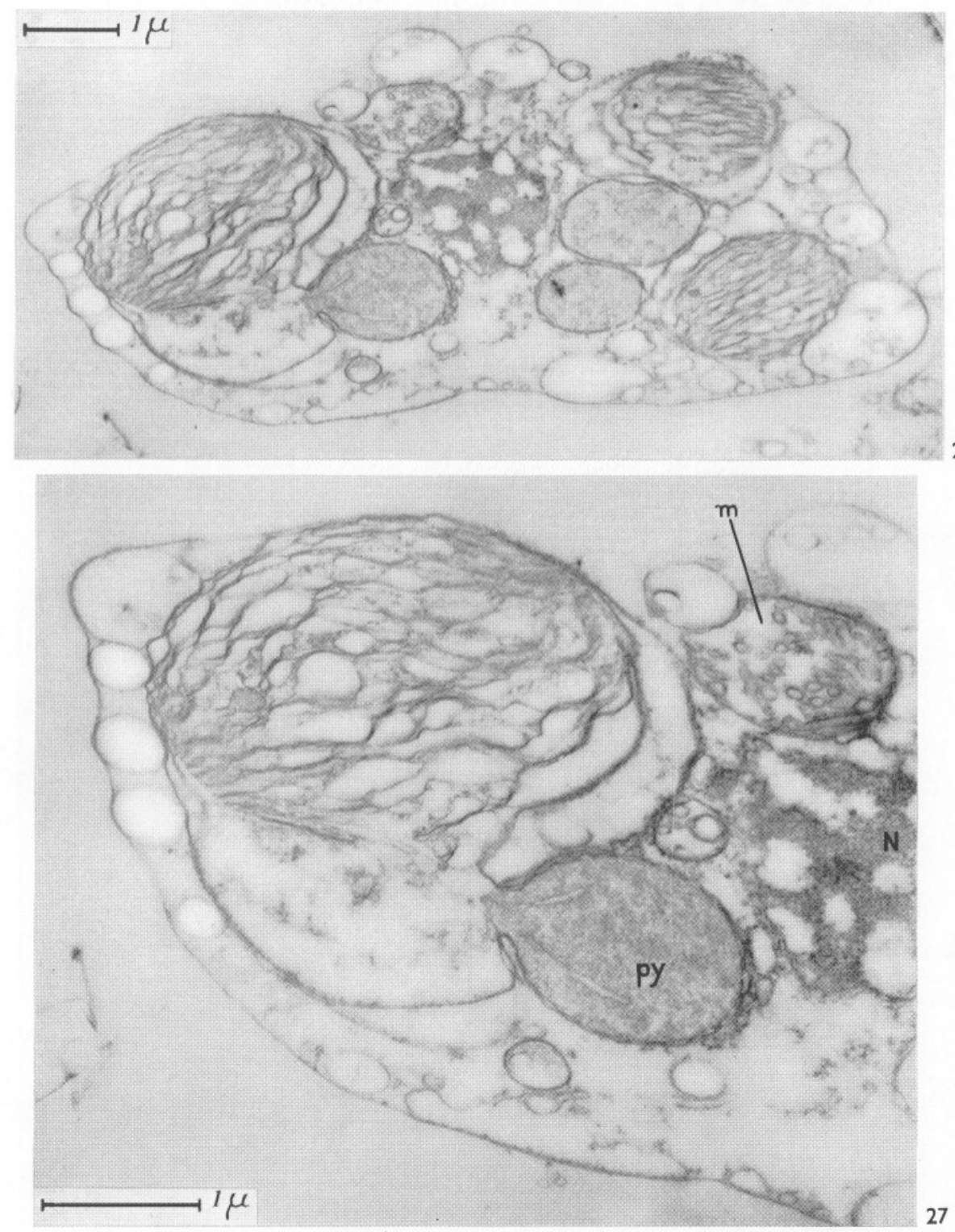

(Facing p. 218) 


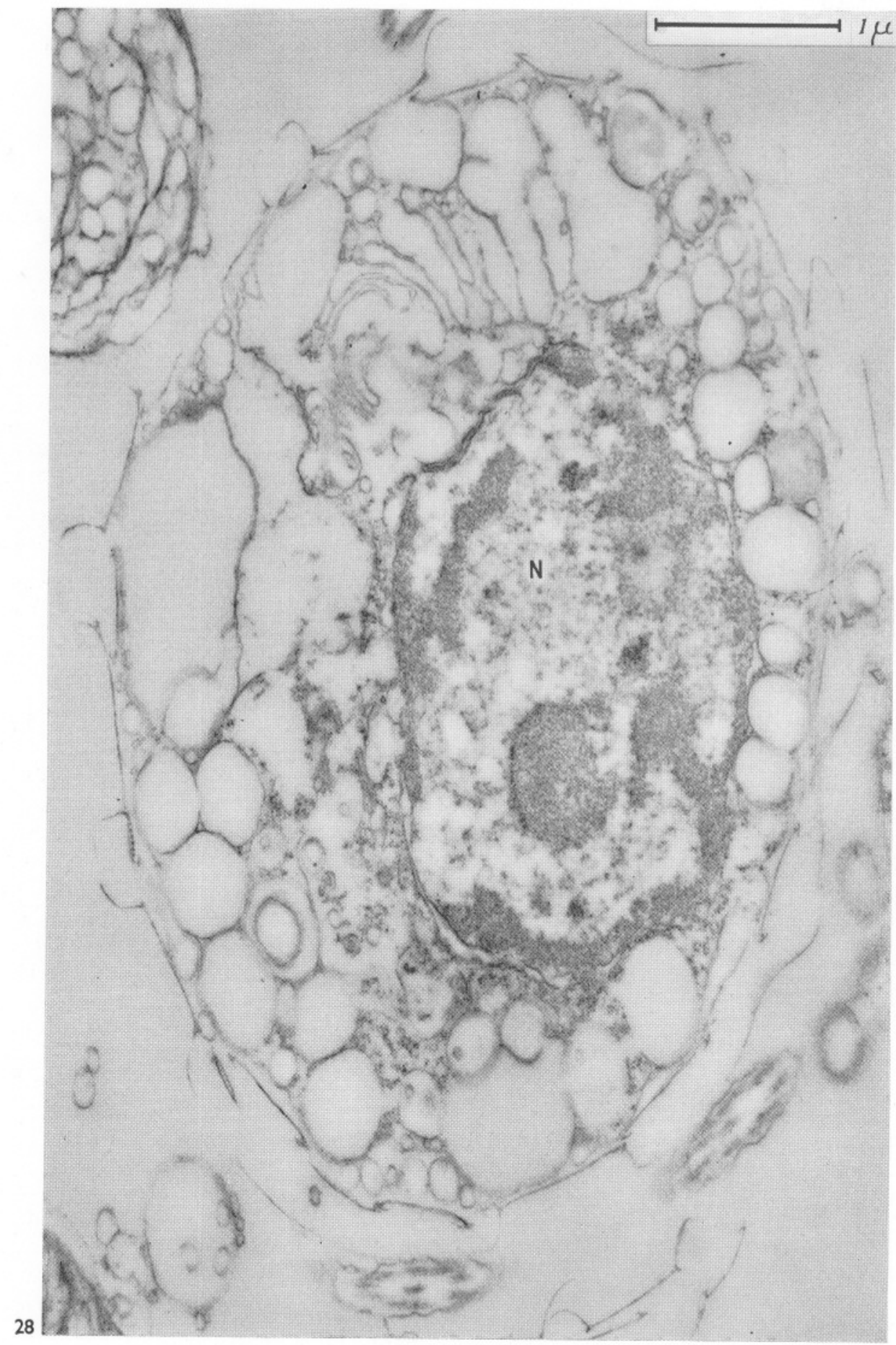



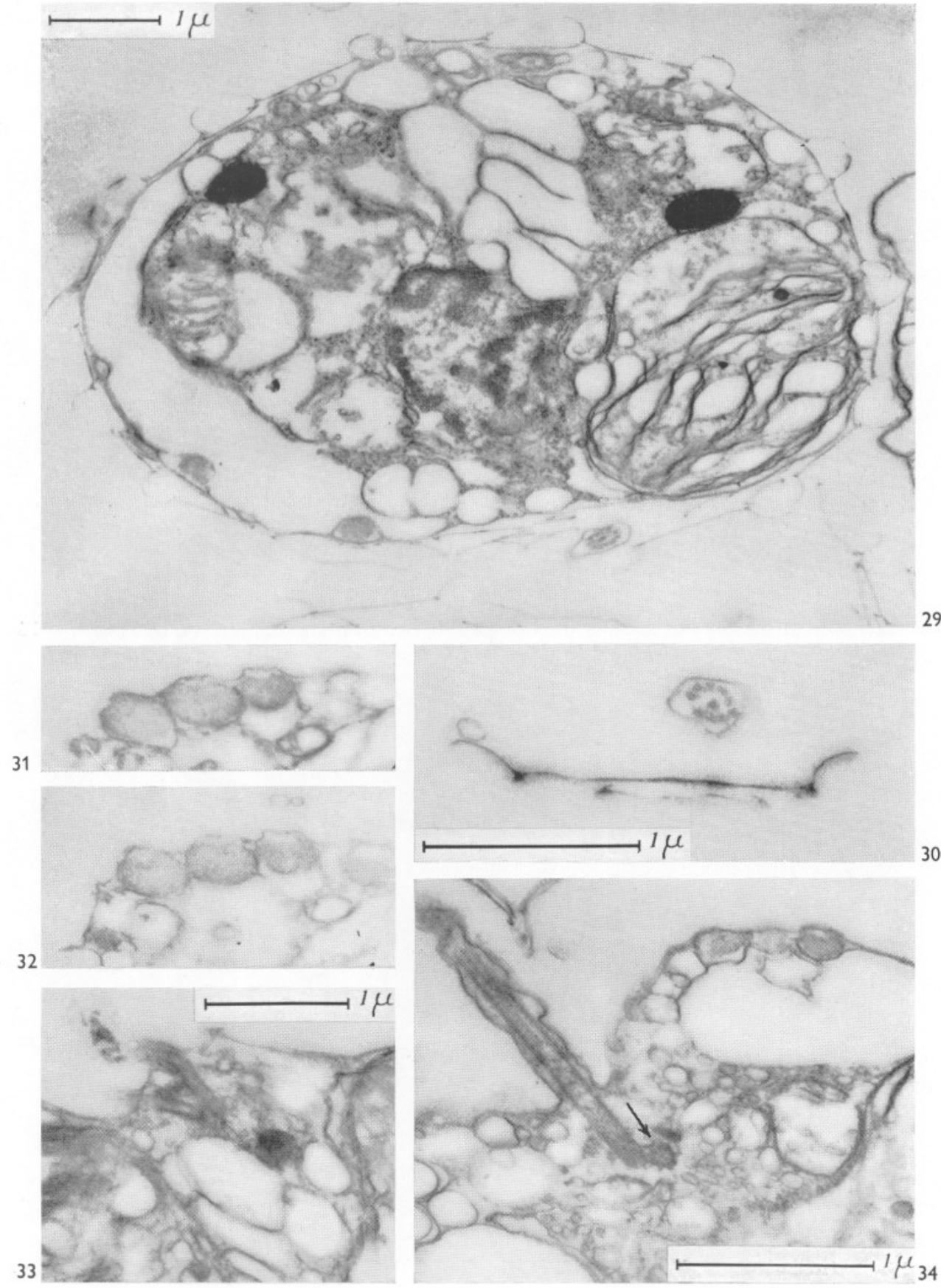

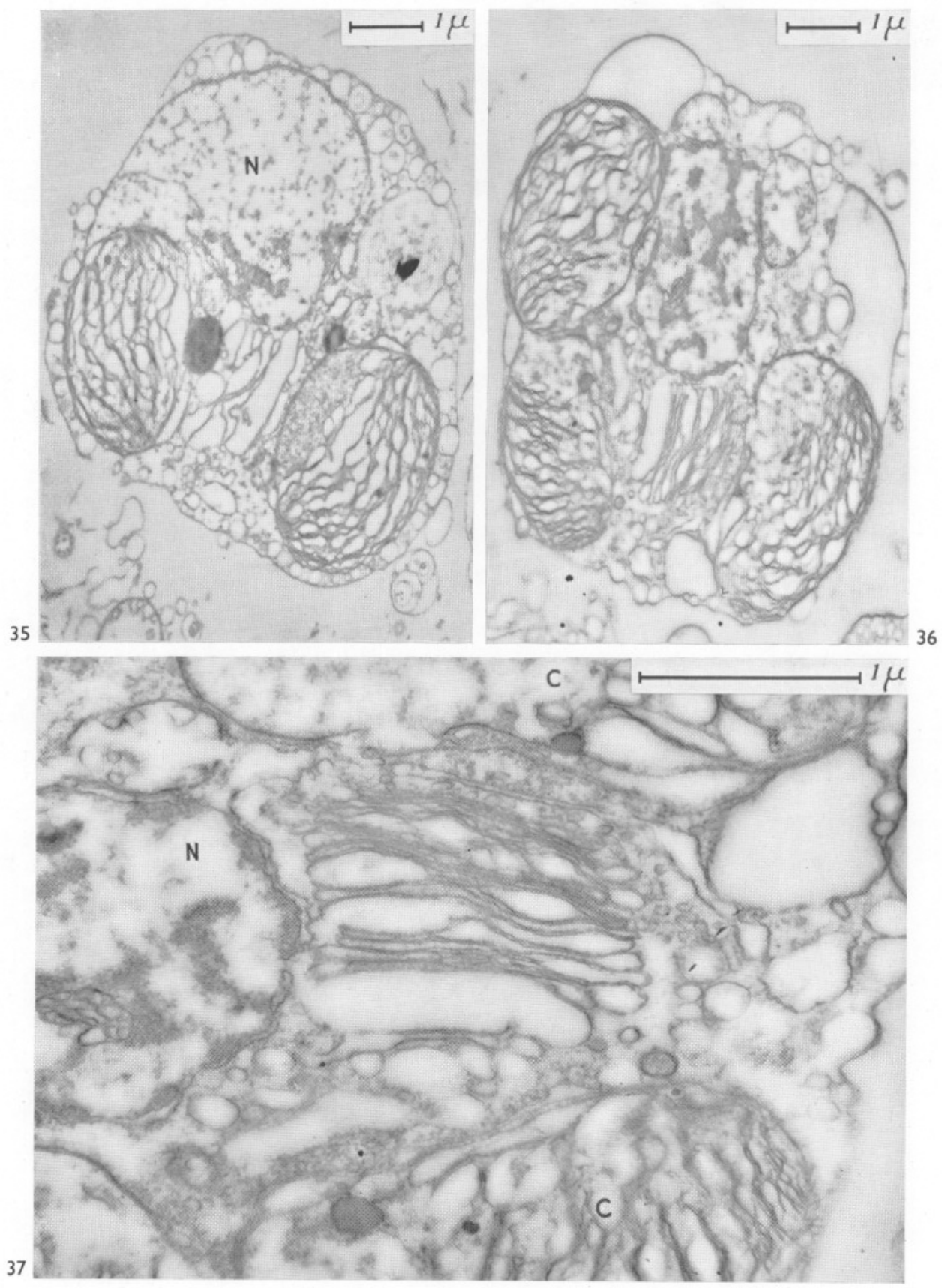
which occur in the cytoplasm. (viii) A number (of the order of 6-8) of granules of fairly uniform size $(0.25 \mu)$ stain with Janus green, which are probably mitochondria. (ix) Janus green also stains faintly one, or more rarely two, much larger bodies of the order of $\mathrm{I} \mu$ in diameter situated near the flagellar pole (see above) and perhaps representing the golgi material identified with the electron microscope (see p. 22I).

The positions of these various components in life are indicated in Figs. I-7 (p. 212), though most of them can change with respect to the flagellar pole in the course of metaboly of the body.

\section{CONTENTS OF THE BODY AS SEEN WITH THE ELECTRON MICROSCOPE}

The criteria for recognizing the internal cell organs with the electron microscope are rather different from those available with the light microscope and many are much more precise. Observations on the living cells have, therefore, been of less help in the interpretation of the sections than might have been expected, but, conversely, it is probable that further study with the light microscope after the identity of the various components has been established might amplify knowledge of function and development. With our present interest concentrated on identification, the principal organs detected with the electron microscope will be briefly described.

\section{The Nucleus}

The nucleus is the most important organ to recognize at the outset since until this is done certain types of sections of it could easily be mistaken for those of other cell components. There is no such difficulty about a section such as that of P1. VIII in which the nucleus is the only major organ visible. It contains a single nucleolus, and the rest of the nuclear volume is occupied by irregularly disposed light and dark masses. The darker material is usually aggregated near to the nuclear surface, sometimes very asymmetrically (cf. Fig. 35), and the size of the aggregates varies also, both types of difference being probably associated with different stages in the nuclear division cycle. Other, more confusing, differences are in the overall shape and position, which undoubtedly change with body metaboly. Thus in Fig. 35, Pl. X, the nucleus is very asymmetrical both in shape and position while that of Fig. 36 is of more normal appearance. Parts of tangential sections showing different views of the dense material in an undoubtedly resting nucleus are contained in Pls. VI and VII and in Fig. 29, Pl. IX.

A detail which cannot profitably be discussed at the present stage is that of the nuclear membrane. This is known to have a highly complex structure in all animals and plants in which it has been carefully examined. To study it effectively requires higher magnification than those used here, but attention 
can be drawn to the part of the nuclear surface included in Fig. 37, Pl. X, and to the nucleus in Pl. VIII to substantiate the statement that in this as in other cells the interior of the nucleus is separated from the body of the cytoplasm not only by membranes but also by a translucent, apparently liquid, layer which, in any one section, appears to be discontinuous but which could equally be a single circum-nuclear vesicle ('cisterna' of Palade \& Porter, I954), or perinuclear space bridged at intervals.

\section{Chromatophores}

Larger than the nucleus and conspicuous in most sections are the chromatophores. These are very easily distinguished by their laminated structure, which is comparable to that of many other lower plants. As in Synura (Manton, I955), Phaeophyceae (Leyon \& von Wettstein, I954; Manton, I957a), etc., the laminae are compound, but they do not here fill the entire organ, much of which seems to consist of storage space. The nature of the storage product is unknown and only small traces of it are still present in most sections. Some granular material and a few osmiophilic vesicles are commonly present between the laminae (Fig. 27, Pl. VII), though the lipoid globules which stain so distinctly with Sudan IV on the fresh material are entirely dissolved by the reagents used for embedding and are only traceable as empty vesicles.

\section{The pyrenoid}

A very distinctive part of the chromatophore is the pyrenoid. When encountered in isolation a pyrenoid in the sense used here is a highly characteristic spherical body, 0.5-I $\mu$ in diameter, containing dense granular material and surrounded by a system of compound membranes. In order to detect attachment to a chromatophore a very special plane of section is required, since there is only a narrow neck joining the two organs. However, a fortunate series of sections showing this feature in two separate pyrenoids in one cell is contained in Pls. VI and VII. The pyrenoid is apparently in continuity with the storage part of a chromatophore, ${ }^{1}$ though the opacity of the contents is very different. We have no interpretation to offer about the other structural details, detectable especially in Fig. 27, P1. VII.

\section{Mitochondria}

Fig. 27, P1. VII, also contains a good example of a mitochondrion (labelled $m$ ). The microanatomy of these organelles is now so familiar that little need be said except to explain that the cylindrical villi which occupy the lumen in place of the cristae of many animal cells differ in no essential way from those of other examples in the lower plants, notably Synura (Manton, 1955), the brown algae (Manton \& Clarke, 1956; Manton, 1957a) and Vaucheria (Greenwood, Manton \& Clarke, I957).

\footnotetext{
1 See footnote on p. 224.
} 


\section{Golgi apparatus}

A slightly less familiar component is illustrated in Pl. X, that has many points in common with the Golgi apparatus of certain animal cells and of some plants, notably Scytosiphon (Manton, 1957), wheat roots (Hodge, Martin \& Morton, 1957), and Sphagnum (Manton, 1957). Attention has already been directed to the position of a compact group of vesicles immediately below the flagellar bases in Fig. 33, P1. IX. Their characteristically flattened and compact arrangement as well as their position in relation to the nucleus and chromatophores are better displayed in Figs. 35 and 36, P1. X. The additional details visible in the more highly magnified micrograph of Fig. 37 are in such striking agreement with those of many published micrographs of golgi in animals that the identification as the same organ here seems virtually unassailable unless on biochemical grounds which have not yet been investigated in this material.

\section{Fat bodies}

Unsaturated fat bodies, easily identifiable as such by their opacity following osmic fixation, are of common occurrence. They are variable in size and not very numerous; two are contained in Fig. 29, Pl. IX, and also in Fig. 35, Pl. X.

\section{Leucosin}

Leucosin in sections is always represented by empty spaces owing to its ready solubility in the alcohols used for dehydration; such spaces are very liable to mechanical distortion, but a demonstrably undistorted cavity bounded by a membrane and almost certainly of this nature is contained in Fig. 29, Pl. IX, beneath the undisturbed covering of scales; parts of very similar cavities are visible in Fig. 34, Pl. IX, and Fig. 36, Pl. X.

\section{Muciferous bodies}

The lenticular vesicles of slightly opaque material visible between the leucosin cavity and the covering of scales in Figs. 29 and 34 are the muciferous bodies. As surmised from their behaviour when seen discharging under the light microscope these are not merely amorphous drops or granules of material but organelles with a definite microanatomy. This has not been completely worked out, but from Figs. 29, 3I, 32 and 34, Pl. IX, it is clear that each organelle is effectively a small-walled compartment with semiopaque contents. There are signs of further subdivision of the contents, notably in the faint white internal contours in the central body of Fig. 3I, and there is certainly anatomical complexity about the outer wall which cannot yet be defined, though characteristic views of relatively median sections can be studied in Figs. 31, 32 and 34. The apparently translucent thickening of the outer wall causes the contents of an undischarged organelle to appear 
somewhat bean-shaped. Further information about the meaning of these structures is greatly to be desired.

\section{The outer membrane}

Covering other parts of the cell, beneath the scales, is a delicate outer membrane. This is demonstrable with special clarity in cells which have lost their scales and is visible in most of those illustrated in Pls. VI, VII and X.

\section{Cytoplasmic vesicles}

The most conspicuous of the other cell contents are the vast array of vesicles, most of them apparently empty, though doubtless not so in life, which crowd the cytoplasm between the other organs and which are specially conspicuous near the outside of the cell (Pls. VI and VII). They are probably of more than one kind but, though none is as yet chemically identifiable, they resemble at any rate superficially the cytoplasmic vesicles commonly encountered in other cells of the lower plants, cf. Scytosiphon (Manton, 1957a).

\section{Food vacuoles}

Food vacuoles are distinguishable from other cytoplasmic vesicles by their irregular contents, which sometimes include recognizable objects such as ingested scales. One food vacuole with rather indefinite contents is present in Fig. 35, Pl. X.

\section{Cytoplasmic granules}

Finally there are cytoplasmic granules. Since extreme metabolic significance has been attributed to certain types of granules (cf. Palade, 1956, etc.), it is important to notice their presence here even though we have no chemical data to add. Granular cytoplasm fills the interstices between vesicles and other cell organs in all parts of the cell. It may be seen specially clearly in Fig. 29, Pl. IX, and Fig. 37, Pl. X.

\section{BEHAVIOUR OF THE LIVING CELL AND REPRODUCTION}

Chrysochromulina chiton shows a marked phototactic response, although there is no obvious stigma and so far no cells lacking chromatophores have been observed.

During swimming the haptonema and flagella are directed backwards, the haptonema usually coiled up close to the body (Fig. I), but sometimes partly or fully extended. Movement can be fairly rapid for short periods, the cells swimming in straight lines rotating slowly with a jerky movement (as if flinging one flagellum round-probably due to excentric insertion on body). The cells are rarely seen moving with flagella and haptonema in front of the body. A characteristic of this species is a gliding movement without rotating, 
with flagella held behind body and with haptonema coiled or extended (Fig. 4). As swimming or gliding slows down, the flagella lie further apart from each other.

Quite long periods of anchorage are common. When anchored the haptonema can be extended to any degree from almost completely coiled to fully extended (Figs. 3 and 7). It is, however, rarely entirely straight (Fig. 4); when extended backwards during swimming it is commonly curved at the tip and when attached it is most commonly bent or slightly coiled (Figs. 2, 3 and 5-7).

Phagotrophy is of very common occurrence, the cells ingesting organisms up to about $3 \mu$ in size (Figs. I-7). The presence of three food vacuoles in one cell at the same time is not uncommon, but one or two is more usual. The method of ingestion is similar to that described for C. ericina (1956, p. 397) and the method of discharge of the contents of the muciferous bodies is as described for C. kappa (1955, p. 589).

Reproduction of the motile stage of $C$. chiton is similar to that described for C. kappa (1955, p. 592), but the lop-sided movement recorded for C. chiton is particularly accentuated in incipient fission stages. Double fission stages are more rarely seen in this species than in C. kappa. Cultures of $C$. chiton reach a density of $I_{2} \frac{1}{2}-2$ million cells $/ \mathrm{ml}$. at the peak of growth. Non-motile stages similar to those already described for the other species $(1955,1956)$ are then produced, but in this species the scale covering of the motile cell appears to remain fairly intact except for a pore through which the contents have come out and masses of these empty 'skins', clearly visible under the light microscope, can be picked up from the bottom of a flask. The large amoeboid and walled cells, both with finely lobed chromatophores, measure from $7 \times 12$ to $9 \times 13 \mu$, while the daughter-cells with smooth thin walls and fairly finely lobed chromatophores measure from $2.5 \times 3$ to $3.5 \times 5 \mu$.

\section{DISCUSSION}

Most of the more obvious comparisons with other organisms have already been made in passing, such comparisons being necessarily limited at present by the relative scarcity of plant cell types which have been effectively studied by these methods. ${ }^{1}$ The most fruitful external comparison at the present stage probably concerns the pyrenoid. This problematical body, or something closely resembling it, has been recognized by light-microscopists in several different groups of non-starch producing organisms (for literature see Fritsch, I935; Chadefaud, I936; Chadefaud \& Feldmann, I949; Magne, I954; etc.),

\footnotetext{
1 A paper (Fauré-Frémiet \& Rouiller, 1957) which is closely relevant to the present inquiry has reached us too late to be discussed in the text. The authors have investigated a species of Chromulina by means of thin sections with the electron microscope. Chromulina differs characteristically from Chrysochromulina in the external appendages and in the presence of an eyespot but shows many points of resemblance in the other body organs.
} 
always as a body external to the chromatophores though possibly connected to them, and characterized by negative staining reactions when tested by most of the ordinary reagents giving diagnostic colouring. Demonstration of organic attachment to an adjacent chromatophore by a long slender neck has been claimed for Ochrosphaera neapolitana (Chrysophyceae) by Schwarz (1932) and Magne (1952). The clarity with which the electron microscope has now revealed, in Chrysochromulina chiton, the attachment of the pyrenoids to adjacent chromatophores by a short constricted neck makes this one of the most definite facts which has so far been ascertained about such pyrenoids. The probability is thus greatly increased that they are in fact storage organs concerned with some product of photosynthesis, which the original choice of the name pyrenoid necessarily implies. A resemblance to the 'plastid diverticulum' recently described (Manton, 1957a) in the zoospores of the brown alga Scytosiphon is also perhaps of importance to note. ${ }^{1}$

Our ignorance of the chemical nature of the contents of pyrenoids only emphasizes what is in fact the most serious gap in our total knowledge of these organisms, and one which requires methods quite other than straight microscopy, namely the general problem of the gross cytochemistry of the cell as a whole. Except for the leucosin, practically nothing is known about the chemical nature of any of the storage products which appear in abundance in various parts of the cell. If this gap could be filled progress in other matters would undoubtedly follow.

An outstanding problem which is both chemical and developmental concerns the structure and mode of origin of the scales, which at present is difficult even to imagine. That there is a delicate cytoplasmic membrane underlying them is a fact which in itself is less explanatory than might at first be thought. The observations on the membrane have necessarily to be made with fixed material, yet we know that in life the cell can engulf solid food through its surface in spite of the covering of scales, etc. The physical nature of the cell surface cannot, therefore, be fully deduced from the anatomical evidence, and we are equally ignorant of the way in which it may perhaps change with time. There are no data, for example, to indicate whether the scales are produced cyclically following a related change in the cell surface prior to their production, or whether they are in fact being produced all the time as a normal process of growth from the surface as we commonly see it. Several details about the shape and arrangement of the scales are difficult to reconcile with the latter view, though anatomy alone is an insufficient guide in such a question.

Purely anatomical information can, however, still add much to our know-

1 Since this was written further information on pyrenoid structure in the Chrysophyceae is available from two sources. Hovasse \& Joyon (1957) describe pyrenoids immersed in the structure of the chromatophore in a species of Hydrurus, and we have found a similar condition in some undescribed species of Chrysochromulina. The special condition of $C$. chiton is therefore not universal in the group. 
ledge of the haptonema, though this must be ascertained comparatively through a range of species before final generalizations can be made. We have shown in $C$. chiton that the anatomical differences from a flagellum are at least as great as had been surmised from their very different behaviour and appearance. We do not, however, yet know the extent of uniformity or diversity within the genus, and in exploring this it is reasonable to hope that our present ignorance about the structure of the extremities, about the mode of attachment to the cell, and, more importantly, about the mechanical principles involved in its movements may also, with further work, be dispelled.

\section{FORMAL TAXONOMIC DIAGNOSIS}

\section{Chrysochromulina chiton sp.nov. Parke \& Manton}

Motile cells showing some metaboly, sphaeroidal to ovoid with a flattened flagellar pole depressed centrally across one axis, 5-8 (exceptionally $4-10$ ) $\mu$ in diameter. Two flagella and one haptonema arising close together slightly offcentre from the depression; the flagella subequal, or of equal length, homodynamic, $2 \frac{1}{2}-3 \frac{1}{2}$ times body length, smooth, apex gradually attenuated to a small knob (E. M. observation); the haptonema, thinner than the flagella, 4-5 times body length when fully extended, with a club-shaped tip and an internal structure of three concentric membranes surrounding a ring of seven 'fibres'. The very thin periplast of a pectic nature covered by very thin, transparent, oval, two-layered, sculptured, exceptionally large, dimorphic scales, visible when dry under the light microscope, details visible only under the electron microscope. Large scales oval, bipartite, saucer-shaped, with a wide rim delimited from an oval centre by a ridge, $\mathrm{I} \cdot 9 \times 2.4$ to $2.2 \times 2.9 \mu$, with the base showing a radiating pattern of ridges on the surface towards the body, the outer surface patternless. The small scales, round to oval, $0.7 \times 0.9$ to $\mathrm{I} \cdot \mathrm{I} \times \mathrm{I} \cdot 4 \mu$, with the relatively patternless rimmed face away from the body and the face with the pattern of radiating ridges towards the body. Scale distribution a single layer over the body with small scales filling interstices between large.

Cells uninucleate, no stigma. Chromatophores appearing striated, usually two or four, occasionally one or six, golden brown; in motile phase usually ellipsoid or oblong, parietal, with a single globular body (pyrenoid) attached by a constricted neck to inner face near one margin slightly nearer to the non-flagellar pole than the flagellar pole; in non-motile phase deeply lobed or stellate. Lipoids and leucosin produced. Ejectile muciferous bodies generally distributed in peripheral cytoplasm but usually more numerous at flagellar pole. Nutrition phototrophic and/or phagotrophic. Non-toxic to fish.

In motile phase asexual reproduction by fission into two, three or occasionally four daughter-cells of equal or unequal size; in non-motile phase reproduction (asexual?) by successive fission of amoeboid cells to produce four daughter- 
cells with thin smooth walls; motile phase probably liberated from walled daughter-cells through a pore.

Isolated by Miss Dorothy Ballantine from sea-water samples collected by her during cruise, May 1955.

Habitat. The sea at position lat. N. $47^{\circ} 36^{\prime}$, long. W. $04^{\circ}$ I $8^{\prime}$ (23 May I955, Plymouth no. I46, type culture) at $50 \mathrm{~m}$; at position lat. N. $47^{\circ} 44^{\prime}$, long. W. $07^{\circ}$ II $^{\prime}$ (I7 May 1955, Plymouth nos. I49, I50) at $5 \mathrm{~m}$; at position lat. N. $50^{\circ} 13^{\prime}$, long. W. $04^{\circ} 22^{\prime}\left(29\right.$ May 1956) at surface; at position lat. N. $50^{\circ} 09^{\prime}$, long. W. $04^{\circ} 16^{\prime}$ (I9 June 1957, very fine tow-net sample); at position lat. N. $50^{\circ} \mathrm{O2}^{\prime}$, long. W. $04^{\circ} 22^{\prime}$ (I6 July 1957) at surface; at position lat. N. $50^{\circ} \mathrm{II}^{\prime}$, long. W. $04^{\circ} \mathrm{I}^{\prime}$ (24 July I957) at surface; at position lat. N. $50^{\circ} \mathrm{O2}$, long. W. $04^{\circ} 22^{\prime}$ (I7 Sept. 1957) at $5 \mathrm{~m}, 10 \mathrm{~m}, 20 \mathrm{~m}$ and $50 \mathrm{~m}$, and at position lat. N. $50^{\circ} \mathrm{II}^{\prime}$, long. W. $04^{\circ} \mathrm{I} 4^{\prime}$ (I5 Oct. I957) at surface. Type culture deposited with the Culture Collection of Algae and Protozoa, Cambridge.

Cellula motilis aliquanto formam mutans, sphaeralis vel ovalis; extremitate, qua inserta sunt flagella, centraliter depressa trans alterem axem; lata 5-8 $\mu$ (rare 4-10 $\mu$ ); duobus flagellis sed et uno haptonemate conjunctim exorientibus paululum remotis depressione centrali; flagellis subaequis vel aequis, homodynamicis, longioribus $2 \frac{1}{2}-3 \frac{1}{2}$ plo quam cellula, teretibus, apicibus paulatim attenuatis sed terminatis minutis bulbis (ut videtur per microscopiam electronicam); haptonemate teneriore quam flagellis, longiore 4-5 cellula maxime extenso, extremitate claviformi; haptonemate induto 3 membranis concentricis, 7 filamentibus axialibus dispositis in annula ut videtur in sectionibus transversis; periplasto tenuissimo, pectico natura, induto tenuissimis, diaphanis, ovalibus, sculptis squamis, grandibus praeter modum, duobus stratis compositis et sub duabus formas existentibus, visibilibus siccis per microscopiam photicam, minuta structura tamen obscura nisi per microscopiam electronicam; squamis majoribus ovalibus, bipartitis, crateriformibus, longis $2 \cdot 4-2 \cdot 9 \mu$, latis I.9$2 \cdot 2 \mu$, lata margine circumscripta ab ovali areola centrali per angustum jugum, cuius areolae aspecto interno, contra cellulae corpus, sculpto radiantibus rugulis, aspecto externo sine rugulis; squamis minoribus circularibus vel ovalibus, longis $0.9-\mathrm{I} \cdot 4 \mu$, latis $0 \cdot 7-\mathrm{I} \cdot \mathrm{I} \mu$, aspecto interno cum radiantibus rugulis, aspecto externo cum jugo circumscribente, sed rugulis relative defectis; squamis distributis unico strato per superficiem cellulae, minoribus replentibus interstices inter majoribus. Nucleo unico, stigmate defecto; chromatophoris apparente striatis, generaliter 2 vel 4 (rare I vel 6), aureobrunneis; in cellulis ad statum motilem chromatophoris generaliter ellipsoidalibus vel oblongis, parietalibus, unico corpore pyrenoidali globulari affixo per isthmum angustum cuique chromatophoro, prope marginem, paululum propiore extremitatem cellulae qua inserta sunt flagella; in cellulis ad statum immotilem chromatophoris profunde lobatis vel stellatis; cellula materias lipoidales et leucosinum producens; ejectilibus corporibus muciferis diffuse distributis in cytoplasmate superficiali, generaliter tamen abundantioribus ad extremitatem cellulae qua inserta sunt flagella. Nutritione phototrophica necnon phagotrophica. Non toxica piscibus.

Cellula ad statum motilem generans per fissionem ad 2, 3 vel rare 4 cellulas filiolas producendas, magnitudine paribus vel disparibus; cellula ad statum immotilem generans (? asexuale) per fissiones sequentes cellularum amoeboidalium ad 4 cellulas filiolas producendas cum parietibus tenuibus et teretibus; ex quibus cellulis filiolis, cellula ad statum motilem per porum liberata (quod maxime potest). 


\section{ACKNOWLEDGEMENTS}

Very grateful thanks are due to Dr K. R. Porter and his colleagues for the use of the RCA microscope at the Rockefeller Institute, New York, during 2 weeks in December 1956, and also to the owners of the Aeon laboratories, Surrey, for the use of their Siemens microscope during 4 days in the spring of 1957 . We are indebted to Dr J. E. Morton of Queen Mary College for translating our specific diagnosis into Latin, and particularly to Miss D. Ballantine for the original collection and preliminary isolation of $C$. chiton and for testing its possible toxicity to fish.

\section{SUMMARY}

The description of a new species of the genus Chrysochromulina, C. chiton, includes for the first time some evidence from the electron microscopy of sections in addition to the techniques previously used. Important diagnostic characters are the exceptionally large scales, which are shown to be of two kinds, the larger being saucer-shaped, and the smaller plate-like with a narrow rim flexed towards the upper surface; the structure and arrangement of the two types of scale on the body are described. Anatomical facts are given for the first time for the internal structure of the haptonema; in this species this organ consists of three concentric membranes surrounding a ring of seven fibres or tubes, the centre of the haptonema being hollow; this combination of characters distinguishes the organ fundamentally from a flagellum. Microanatomical facts are also given for the following major cell organs: the nucleus, the chromatophores including the pyrenoids, mitochondria, putative golgi material, muciferous bodies, the flagellar bases (preliminary observations only). Other distinguishable cytoplasmic components include the surface membrane, unsaturated fat bodies, vesicles of various kinds and granular protoplasm in the interstices.

\section{REFERENCES}

Chadefaud, M., I936. Le Cytoplasme des algues vertes et des algues brunes. Ses éléments figurés et ses inclusions. Rev. algol., T. 8, pp. 5-286.

Chadefaud, M. \& Feldmann, J., I949. Sur une Coccolithophoracée des bacs de l'aquarium de la Station biologique de Roscoff. Bull. Mus. Hist. nat., Paris, Sér. 2, T. 2I, No. 5, pp. 617-2I.

DofleIN, F., I922. Untersuchungen über Chrysomonadinen. I. Ochromonas granularis Dofl. Arch. Protistenk., Bd. 44, pp. I47-205.

FAURÉ-FRÉMIET, E. \& RouIlleR, C., 1957. Le flagelle interne d'une Chrysomonadale: Chromulina psammobia. C.R. Acad. Sci., Paris, T. 244, pp. 2655-2657.

Fritsch, F. E., 1935. The Structure and Reproduction of the Algae. Vol. I, 791 pp. Cambridge University Press.

Greenwood, A. D., Manton, I. \& ClarKe, B., 1957. Observations on the structure of the zoospores of Vaucheria. F. exp. Bot., Vol. 7, pp. 7I-86. 
Hodge, A. J., Martin, E. M. \& Morton, R. K., I957. The structure of some cytoplasmic components of plant cells in relation to the biochemical properties of isolated particles. F. biophys. biochem. Cytol., Vol. 3, pp. 6I-70.

Hovasse, R. \& Joyon, L., 1957. Sur l'ultrastructure de la Chrysomonadine Hydrurus foetidus Kirchner. C.R. Acad. Sci., Paris, T. 245, pp. I IO-13.

LACKEY, J. B., I939. Notes on plankton flagellates from the Scioto River. Lloydia, Vol. 2, pp. I28-43.

Leyon, H. \& Wettstein, D. von, 1954. Der Chromatophoren-Feinbau bei den Phaeophyceen. Z. Naturf., Vol. 9 B, pp. 472-5.

MAGNE, F., I952. Sur la cytologie d'une Chrysophycée marine vivant en aquarium, Ochrosphaera neapolitana Schussnig. Rev. gén. Bot., T. 59, pp. 23I-3IO.

- 1954. Les Chrysophycées marines de la Station biologique de Roscoff. Rev. gén. Bot., T. 6I, pp. 389-4I5.

Manton, I., 1955. Observations with the electron microscope on Synura caroliniana Whitford. Proc. Leeds phil. lit. Soc., Vol. 6, pt. 5, pp. 306-3I6.

- I957a. Observations with the electron microscope on the internal structure of the zoospore of a brown alga. F. exp. Bot., Vol. 8, pp. 294-303.

- $1957 b$. Observations with the electron microscope on the cell structure of the antheridium and spermatozoid of Sphagnum. F. exp. Bot. (in the Press).

MANTON, I. \& ClaRKE, B., I956. Observations with the electron microscope on the internal structure of the spermatozoid of Fucus. F. exp. Bot., Vol. 7, pp. 4r6-432.

PALADE, G. E., I956. Electron microscopy of mitochondria and other cytoplasmic structures. Henry Ford Hospital Symposium on Enzymes, pp. 185-215. New York: Academic Press.

Palade, G. E. \& Porter, K. R., 1954. Studies on the endoplasmic reticulum. I. Its identification in cells in situ. F. exp. Med., Vol. 100, pp. 64I-56.

PARKe, M., MANTON, I. \& Clarke, B., I955. Studies on marine flagellates. II. Three new species of Chrysochromulina. F. mar. biol. Ass. U.K., Vol. 34, pp. 579-609.

—_ 1956. Studies on marine flagellates. III. Three further species of Chrysochromulina. F. mar. biol. Ass. U. K., Vol. 35, pp. 387-4I4.

SchwarZ, ElisabeTH, I932. Der Formwechsel von Ochrosphaera neapolitana. Arch. Protistenk., Bd. 77, pp. 434-62. 